\title{
石炭化学の最近の進歩 (そのII)
}

\section{石炭の水素化分解とその生成物の利用}

\author{
平 尾一郎* ・藤 本勉* \\ Recent Progress of Coal Chemistry. Part II \\ Hydrogenation of Coal and Utilization of its Products. \\ Ichiro HiraO*, Tsutomu FujImoto
}

\section{I. 緒言}

さきに石炭化学の新しい分野である石炭の酸化と, 酸 化生成物であるベンゼンカルボン酸類の利用について述 べたが, 今回は石炭の水素化分解について最近の研究を 概観し, あわせて水素化分解生成物の利用について検討 することにする。

\section{II. 石炭の水素化分解の動向}

石炭の水素化分解は 1913 年, ドイツの Bergius によ って行なわれた。彼は $100 \mathrm{~atm}$ の水素加圧下に石炭を $450^{\circ} \mathrm{C}$ に加熱し，液状生成物を $85 \%$ の収率で得た。こ の方法は石炭より液体燃料を製造する方法としてドィ ツ, 英国やわが国など石油資源の之しい国で研究され, ドイツでは工業化することに成功し, 第二次大戦中石炭 よりガソリンを製造していた"1)。この方法は 2 3. 段階 に分けて石炭の水素化分解を行なってガソリンを製造す るもので, 褐炭のような比較的炭化度の低、石炭は重質 油に想濁させ, 微砕したウインクラーコークスに水酸化 鉄を付着させて焼成した 触媒を添加し，230 300 atm., $430 \sim 490^{\circ} \mathrm{C}$ の反応条件で水素化分解を行ない，あるい は炭化度の進んだ歴青炭を原料に用いるときは石炭の反 応性が低いため, 触媒作用の強いシュウ酸スズ・塩化ア ンモンを触媒として $, 460^{\circ} \mathrm{C}, 300 \mathrm{~atm}$. で反応させるか, 硫化鉄を触媒として $480^{\circ} \mathrm{C}, 700 \mathrm{~atm}$. の条件で反応さ せ，生成した重質油はペースト油として循環して使用し 中油は $\mathrm{WS}_{2}, \mathrm{CoS}, \mathrm{MoS}_{2}$ などの触媒を使用し, 水素化 を繰返してガソリンを得ていた。

* 九州工業大学工業化学教室（北九州市戸畑区中原）
第二次世界大戦後はドイツの石炭の水素化分解による ガソリン製造は中止されるに至り，現在では企業的に実 施しているところはない。しかし U.S. Bureau of Mines はアメリカにおける将来の石油需給関係を考虑し, 石油欠乏対策の一つとして石炭の水素化分解によるガソ リンの製造研究を1949 年より開始した ${ }^{2)}$ 。彼らは 7900 $\sim 8300 \mathrm{lb}$./in ${ }^{2}$ gage, $850 \sim 880^{\circ} \mathrm{F}$ の条件で, 硫酸鉄を触

表 1

\begin{tabular}{|c|c|}
\hline $\begin{array}{l}\text { 運転条件 } \\
\text { 压力 }\left(\mathrm{lb} / \mathrm{in}^{2}\right) \\
\text { 反応温度 }\left({ }^{\circ} \mathrm{F}\right), \text { 第一反応機 } \\
\quad \text { 第二反応機 } \\
\text { ペースト量/石炭 (gal } / \mathrm{ton} .) \\
\text { 石炭消費量 (ton } / \mathrm{day}) \\
\text { 石炭仕込速度 }\left(\mathrm{lb} / \mathrm{ft}^{3} / \mathrm{hr}\right) \\
\text { 水素量 }\left(\mathrm{fo}^{3} / \mathrm{ton}\right) \\
\text { 水素消費量 (石炭に対して\%) } \\
\text { 液化率 }(\%, \text { 石炭に対して) } \\
\text { ガス化率 (\%, 石炭に対して) }\end{array}$ & $\begin{array}{r}7900 \\
866 \\
861 \\
486 \\
57.1 \\
26.4 \\
188.1 \\
9.8 \\
94.2 \\
12.1 \\
\end{array}$ \\
\hline $\begin{array}{l}\text { 物質収支 } \\
\text { 原 料 } \\
\text { 石炭 (無水無灰炭) } \\
\text { 反応水素 } \\
\text { 生成物 } \\
\text { 炭化水素ガス } \\
\mathrm{CO}+\mathrm{CO}_{2} \\
\text { ガソリン } \\
\text { ナフサ } \\
\text { 中 油 } \\
\text { ベンゼン可溶重油 } \\
\text { 未溶解炭 } \\
\text { 水 } \\
\mathrm{H}_{2} \mathrm{~S} \\
\mathrm{NH}_{3} \\
\end{array}$ & $\begin{array}{r}1000 \\
59.2 \\
\\
136.2 \\
19.0 \\
88.7 \\
174.3 \\
316.5 \\
111.2 \\
49.1 \\
90.7 \\
19.7 \\
8.1 \\
\end{array}$ \\
\hline
\end{tabular}


媒として用いて，石炭を約 95\% の液化率で水素化分解 している (表 1 参照)。生成した液化軽油は, $\mathrm{Zn}-\mathrm{Cr}-\mathrm{Mo}$ 系触媒を用いて，10200 $10300 \mathrm{lb} / \mathrm{in}^{2}$ gage, 870 920 の条件で水素化してガソリンを製造するとともにベンゼ ン，フェノールなどの芳香族炭化水素およびタール酸を 分離して, 化学原料として製品化するものである。彼ら はこれらの実験結果にもとずいて工業化の経済的問題を 検討し, 芳香族炭化水素, タール酸などを商品化するこ とによりガソリン製造のコストを有利にしうることを明 らかにしだっ。

このようにして石炭を水素化分解してガンリンだけで なく, 芳香族炭化水素やフェノール類を分離して化学原 料を供給しようとする動きがみられるに至った。この考 えをさらに押し進め, 石炭の水素化分解にタール酸の回 収，中油のプラットホーミングを組合せてフェノール類 と低級芳香族炭化水素を製造する計画が Koppers Co. の E.E. Donath ${ }^{4}$ によって提案された。彼はまた，夕 一ル酸を炭化水素存在下で触媒を用いないで高圧水素化 分解を行なうと低級フエノール類を収率よく生成すると いう H. Storch ${ }^{5}$ らの研究にもとずいて計画を改良し だ)。この計画は生成油からタール酸およびメタノール 抽出によるタール酸濃縮油を水素化分解するとともに， 中油をプラットホーミングにかけて改質するもので（図 1 参照), フェノールおよびベンゼンの生産量が増加し ている (表 2 参照)。Donath の計画の石炭を水素化分 解して, 積極的に芳香族炭化水素およびフエノール類を 製造しようとする考えは興味あるが，高圧水素化反応を 幾段にも行なう点が不利である。

石炭の構造の特質を有効に活用して芳香族炭化水素,

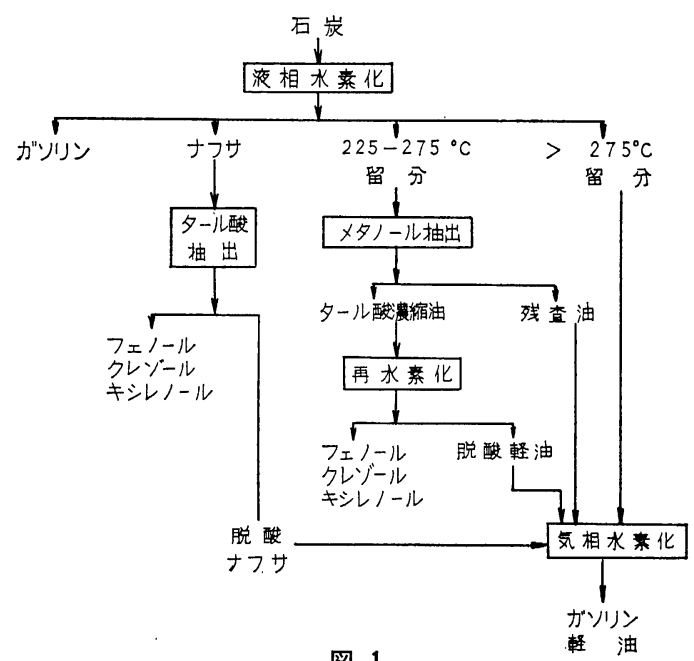

図 1

\begin{tabular}{|c|c|c|}
\hline 製 & $\begin{array}{l}\text { Donath 計画I } \\
\text { 二段水菜化 } \\
+\mathrm{PF} * \\
\quad(\mathrm{bbls} / \mathrm{d})\end{array}$ & $\begin{array}{l}\text { Donath計画 II } \\
\text { 二段水䒺化 } \\
+ \text { タ-ル酸水 } \\
\text { 素化+PF* } \\
(\mathrm{bbls} / \mathrm{d})\end{array}$ \\
\hline フェノール & 428 & 845 \\
\hline oークレゾール & 48 & 45 \\
\hline 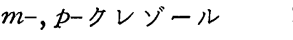 & 530 & 450 \\
\hline キシレノール & 347 & 200 \\
\hline ベンゼン & 2,210 & 4,570 \\
\hline トルエン & 3,770 & 3,310 \\
\hline キシレン & 4,190 & 3,670 \\
\hline 芳香族化合物の混合物 & 1,780 & 0 \\
\hline エチルベンゼン & 750 & 0 \\
\hline ナフタリン & 790 & 0 \\
\hline ガゾール & 7,300 & 7,700 \\
\hline ガソリン & 8,920 & 9,750 \\
\hline
\end{tabular}

原料石炭: $16,000 \mathrm{t} / \mathrm{d}$

*PF : プラットホーミンク

フェノール類，キノリン類などを製造しようという新し い構想のもとに石炭の一段水素化分 解法が Carbide \& Carbon Chemical Co. で開発された ${ }^{7)}$ この方法は反応温 度 $428 \sim 556^{\circ} \mathrm{C}$, 圧力 $278 \sim 408 \mathrm{~atm}$., 触媒量は回収の必 要のない程度 $(0.1 \sim 0.5 \%)$ 添加し，反応時間 3〜4.5

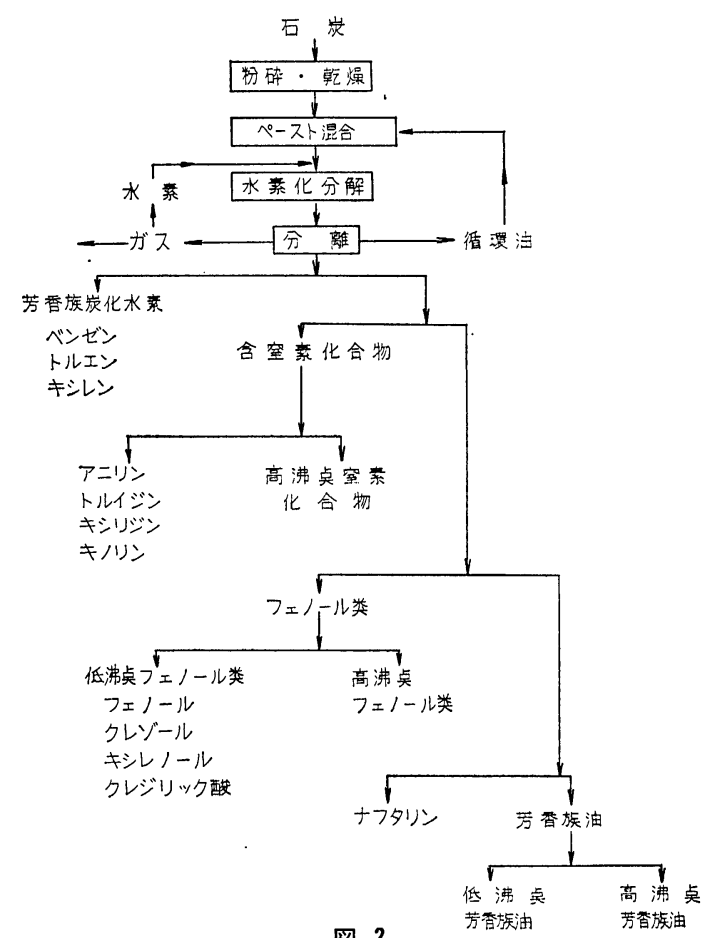


min といわれている。この反応条件は燃料油製造を目的 とした水素化分解の条件と比較して反応時間が非常に短 かく, 反応温度が高いのが特徴である。したがって水素 化分解を徹底的に行なわず, 途中で止めて低度に水素化 分解を行ない，極性物質をも製造しようとする方針のよ うで，生成物は複雑となり，おのおの成分に分離するこ とが困難となる (図 2 参照)。生成物収量は高温乾留の 場合と比較して，フェノール 60〜80 倍，クレゾール100 〜200 倍, キノリン 300〜500 倍, ナフタリン 3〜8倍と いわれている。しかしこの方法は $300 \mathrm{t} / \mathrm{d}$. の規模で試験 研究が行なわれたにもかわらず，まだ企業化されていな いようである。

\section{III. 石炭の水素化分解の最近の動向}

最近の石炭の水素化分解による燃料油の製造に関する 研究に Hiteshue らの ${ }^{8)}$ 反応温度, 反応時間の影響を検 討した研究がある。彼らは硫化スズを石炭に対して 0.1 wt \% 添加し, $240 \mathrm{~atm}$, , 420 480 ${ }^{\circ} \mathrm{C}$ で水素化分解を行 なって検討し，反応時間がながくなるにしたがって，ま た反応温度が上昇するにしたがって生成物の低分子化が 進行するため炭化水素ガスの収率は增大し, 生成した重 質油の粘度は低下し, 酸素, 窒素およびイオウは容易に 水，アンモニア，硫化水素となって除去されるようにな る。液状生成物は 76〜85\% (Pittsburgh 炭)，60８5\% (Rock Springs 炭) の収率で得られており，燃料油製 造の最適条件として, Rock Springs 炭に対しては 440 $\sim 480^{\circ} \mathrm{C}$ で $0.2 \sim 1.0$ 時間，また Pittsburgh 炭に対し ては $420 \sim 460^{\circ} \mathrm{C}$ で $0.3 \sim 1.0 \mathrm{hr}$ の反応条件を示してい る。

その他 $\left(\mathrm{NH}_{4}\right)_{2} \mathrm{MoO}_{4} \cdot \mathrm{NiCl}_{2}$ (あるいは $\left.\mathrm{SnCl}_{2}\right)$ を触 媒とし, $500^{\circ} \mathrm{C}$ 以上, $475 \mathrm{~atm}$ 以上, 反応時間 $15 \mathrm{~min}$ の条件下に液相で石炭を水素化分解して，一段で芳香族 炭化水素に富んだ モーター油を製造する方法")，石炭を 水素化分解して得た液化油を $\mathrm{NiS} \cdot \mathrm{WS}_{2}$ 触媒で $300^{\circ} \mathrm{C}$, $230 \mathrm{~atm}$ の条件で再水素化してガソリンを製造するもの 10)，あるいはテトラリン，デカリン，ビフェニルなどの 水素供給性の溶媒中で石炭を $350^{\circ} \mathrm{C}$ 前後に加熱し, 石炭 中の比較的熱分解を受け易い部分を熱分解して抽出し, また残査からは一度 $510^{\circ} \mathrm{C}$ で炭質化したのち, $\mathrm{MoO}_{3}$ ・ $\mathrm{CoO} \cdot \mathrm{Al}_{2} \mathrm{O}_{3}$ 触媒を用いて水素化分解して 液化油を製造 しようとする溶剤抽出処理を組合せた方法もある ${ }^{11)} 。$

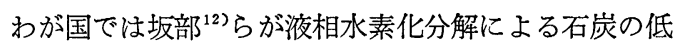
分子化を人造石油製造の場合と同様におこない，主生成 物である中軽油からフェノールおよび塩基性物質を分離 し, 中性部分を脱アルキル化, 脱水素して分離し易く,
しかも需要の多い化合物を製造する計画のもとに連続試 験装置を用いて三池炭の高圧液相水素化分解を行ってい る。彼らは三池炭を $300 \mathrm{~atm} ., 450^{\circ} \mathrm{C}$ の条件で赤泥触媒 を使用して水素化分解し, 液化しており, 物翼収支, 生 成率，中軽油と炭化水素ガスの性状，組成など詳細に検 討している。主生成物である中軽油は $0.15 \sim 0.18 \mathrm{~kg} / l /$ hr. の生成速度で, 無水無灰炭に対して 60.3 62.2\% の収率で得られて㧍り，石炭の分解率は 96〜97\% に達 している。中軽油中には中性油が 76.6〜84.5 wt\% を しめ，その他酸性油および塩基性油がそれぞれ 11.0 $14.8 \mathrm{wt} \%, 3.9 \sim 6.4 \mathrm{wt} \%$ 含まれている。炭化水素ガス の生成収率は約 $27 \%$ で， $\mathrm{C}_{1 \sim 4}$ の飽和炭化水素からなる が，その組成は $\mathrm{CH}_{4} 27 \sim 32 \%, \mathrm{C}_{2} \mathrm{H}_{6} 25 \sim 26 \%, \mathrm{C}_{3} \mathrm{H}_{8} 25$ 〜29\%, $\mathrm{C}_{4} \mathrm{H}_{10}$ 17〜18\% となっている。

その他に石炭を液相で $500 \sim 560^{\circ} \mathrm{C}, 400 \sim 6000 \mathrm{lb}$./in ${ }^{2}$ gage の加圧下で水素化分解し，ガス生成物 (14\%), 軽 油 $(16 \%)$, 中油 $(7 \%)$ および重油を製造する特許 ${ }^{13)}$ ある。中軽油中にはフェノール類が石炭に対して約 $4 \%$ 含まれており，インドール類も15〜30\% 含まれている といわれている。

石炭の水素化分解によって得られる液状生成物はアル キル置換芳香族化合物や，飽和環状化合物など多種類の 混合物であるが，これを再度水素化を行なって簡単な組 成の芳香族化合物に変化させようとする特許 ${ }^{14)}$ がある。 石炭の水素化分解で得られる軽油, 中油, 重油およびピッ チと重油の混合物などを耐圧反応管を用いて，550～650 ${ }^{\circ} \mathrm{C}$ の比較的高温で, $136 \sim 238 \mathrm{~atm}$ の加圧下に, 4 20/1 （モル比）の水素を供給し, 触媒を使用せずに, 滞留時 間 5〜10 min で水素化を行なうものである。この反応は 要するに高温, 高圧で多量の水素を使用して, 短時間で アルキル芳香族化合物の脱アルキル化および芳香族化を 行なって，原料油の複雑な組成を分離し易い簡単な芳香 族化合物の組成に変えるものである。反空条件のうち特 に反応温度の影響が大きい。たとえば，この反応の進行 度を反応生成物中のベンゼン, トルエン, ナフタリンの 合計の含有率であらわすと, 水素供給量 $7.8 / 1$ (モル比) 反応圧力 $204 \mathrm{~atm}$, 滞留時間 $5 \mathrm{~min}$ の反応条件で, 軽 油を反応させたときの反応温度の影響を 表 3 に示した。

表 3

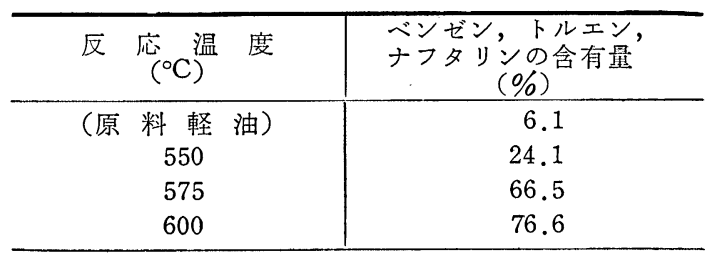


液状生成物の収率は轻油の場合は約 $50 \%$ 程度で, その他 の原料を使用した場合は約 $80 \%$ 程度とのことである。

石炭の水素化分解は高温, 高圧を必要とするため, 装 置的にも技術的にも種々の問題があり，高温，高圧技術 が進歩した今日においてもできるだけ穏和な条件で反応 させることが望ましい。また石炭の水素化分解の目的に 合致した方向に反応を促進できれば，石炭の水素化分解 反忘を一層有意義なものにするであろう。ドイツにおけ る石炭の水素化分解に用いられた触媒は, 褐炭に対して 注酸化鉄が，歷青炭に対しては強力な触媒作用をもつシ ュウ酸スズが用いられたが，のちには $700 \mathrm{~atm}$ の加圧下 で酸化鉄・硫酸鉄・硫化ナトリウムが用いられた。これ は高圧技術の進歩とともに高価で腐食性に問題のある強 力な触媒を用いるよりも安価な鉄系触媒を用いる方が有 利であったものと考えられる。

触媒に関する最近の研究に Hiteshue ${ }^{8)}$ らの $\mathrm{Sn}, \mathrm{Ni}, \mathrm{Fe}$, Zn の触媒作用を比較検討した研究がある。彼らは Rock Springs 炭を用いて $240 \mathrm{~atm} ., 460^{\circ} \mathrm{C}$ の反忘条件で水素 化分解して触媒作用を比較検討し, 石炭の変化率で触媒 作用を比較すると反応時間 $0.45 \mathrm{hr}$ では Sn が最も高い 変化率をしめし, つぎの順に 変化率は低下し, $\mathrm{Zn}$ の場 合の変化率は非常に悪いことをしめした。

\section{$\mathrm{Sn}>\mathrm{Ni}, \mathrm{Fe}>\mathrm{Zn}$ (石炭の変化率による比較)} しかし，反応時間が $0.8 \mathrm{hr}$ になると，これらの触媒に よる石炭の変化率の差はほとんど認められなくなってい る。触媒作用を沸点 $355^{\circ} \mathrm{C}$ 以下の液体生成物の収率で比 較すると, 反応時間 $0.45 \mathrm{hr}$ ではつぎの順に触媒作用は 低下し，変化率で比較した場合と同様の結果を得ている が, 反応時間 $0.8 \mathrm{hr}$ となると $\mathrm{Sn}$ が最も良好な結果を 示し, 他の触媒作用には差異が認められなくなっており 変化率で比較した場合と幾分異なった結果を得ている。

$\mathrm{Sn}>\mathrm{Fe}>\mathrm{Ni}>\mathrm{Zn}$ (液体生成物の収率による) 反応時間 $0.8 \mathrm{hr}$ に打ける液体生成物の収率は Sn 触媒 が最もよく，他の触媒の差異はほとんど認められなかっ た。

同様に $460^{\circ} \mathrm{C}, 100 \mathrm{~atm}$. の条件で $\mathrm{Sn}, \mathrm{Mo}, \mathrm{Ni}, \mathrm{Fe}$ の 触媒作用を比較すると，反忘時間 $0.6 \mathrm{hr}$ における石炭 の変化率は, $\mathrm{Mo}>\mathrm{Sn}>\mathrm{Ni}>\mathrm{Fe}$ の順に低下し，Moが良 好な結果を示したが, 反応時間 $1.0 \mathrm{hr}$ ではこれらの触 媒による石炭の変化率の差異はほとんど認められなかっ た。しかしながら沸点 $355^{\circ} \mathrm{C}$ 以下の液体生成物の収率を 比較すると, 反応時間 $0.6 \sim 1.0 \mathrm{hr}$ において, $\mathrm{Sn}>\mathrm{Mo}$ $>\mathrm{Ni}>\mathrm{Fe}$ の順に低下している。したがって, Sn, Moの 触媒作用がすぐれており，しかもこれらの触媒にいくら かの選択性がみられることは興味ぶかい。
触媒の添加量は回収する必要がない程度の少量である ことが望ましい。一般に Mo 系触媒は石炭に対して $1 \mathrm{wt}$ \%程度添加されるが, Hiteshue ら ${ }^{15)}$ はモリブデンアン モンを石炭に対して Mo で 0.01 wt \% 添加して, 石炭 のガス状炭化水素と液状生成物への変化率を検討し, $460 \sim 480^{\circ} \mathrm{C}, 545 \mathrm{~atm}$ の条件で，98９9\% の変化率でガ ス状炭化水素と液状生成物を得ている。

Hiteshue $~{ }^{16)}$ はまた石炭の液相水素化分解を行なう ときの触媒の添加方法について $400 \sim 500^{\circ} \mathrm{C}, 580 \sim 680$ atm の条件で，触媒として Mo を $0.01 \% ， 0.1 \% ， 1 \%$ 添加して, 触媒をあらかじめ石炭に浸付させる添加法と 石炭とペースト油の泥状物に触媒を添加する方法とを比 較検討しているが，いずれの場合も同様な結果を得てお り, 反応時間 15～60 min で石炭の変化率 $98 \%$ 以上に 達している。

その他イオウ含有量の多い石炭の水素化分解の触媒を $400^{\circ} \mathrm{C}, 100 \mathrm{~kg} / \mathrm{cm}^{2}$ の条件で $5 \mathrm{hr}$ 水素化分解を行なっ て検討し, Hematite, Magnetite, Mill scale などは Sn $\mathrm{S}_{2} \cdot \mathrm{NH}_{4} \mathrm{Cl}$ 触媒と同様の効果が認められたが, 硫酸鉄, 塩化亜鉛などの触媒作用はほとんど認められなかったと いう報告 ${ }^{17)}$ もる。

また Hiteshue ら ${ }^{18)}$ は $400^{\circ} \mathrm{C}, 450^{\circ} \mathrm{C}, 538^{\circ} \mathrm{C}$ の各反応 温度で, 反応圧力 $34,68,136 \mathrm{~atm}$ のおのおの場合につ いて触媒を使用 せずに石炭を水素化分解し, 反応時間 0.1 14.5 min の間の石炭の変化率を検討している。い ずれの場合も石炭の変化率は最初の $3 \mathrm{~min}$ の間に急速に 増大し, 以後は漸次増加している。反応時間, 温度, 圧 力と石炭の変化率の関係を求めており, $900^{\circ} \mathrm{C}$ に反応温 度を上昇すると反応時間は約 $1 \mathrm{~min}$ で好結果をもたら し, ガス状炭化水素の生成に適するようになることを示 した。

一般に石炭を水素化分解して中軽油を得るには反応温 度 $450 \sim 480^{\circ} \mathrm{C}$, 反応圧力 $200 \sim 550 \mathrm{~atm}$ の反応条件で 水素化分解を行ない,液状生成物を約 $60 \%$ 程度得るとと もにガス状炭化水素が約 $20 \%$ 程度副生するものである が, Hiteshue ら ${ }^{19}$ は反応温度を $800^{\circ} \mathrm{C}$ に上昇させ, 約 $400 \mathrm{~atm}$ の加圧下に, 触媒としてモリブデンアンモンと 硫酸を用いて, 短時間石炭を水素化分解して, 反応生成 物の収率の変化を検討している。その結果によると，反 応時間 0 (反応温度 $800^{\circ} \mathrm{C}$ に達するとただちに泠却し て反応を中止させた場合)で石炭の変化率はすでに 65〜 68\% になり，反応時間 $15 \mathrm{~min}$ では $90 \%$ の変化率に達 している。ガス状炭化水素の収率は 反応時間 0 で 38\% に達し，反忘時間が増加するにしたがって漸次増加して いる。液状生成物の収率は反応時間 $1 \mathrm{~min}$ で $9 \%$ に達 
したのちはほとんど増加していない。なお，生成した炭 化水素ガスの組成はメタンが $90 \mathrm{vol} \%$ をしめ, 残りは ほとんどエタンである。

彼ら ${ }^{20)}$ はひきつづいて $800^{\circ} \mathrm{C}, 408 \mathrm{~atm}$ の条件下に水 素化分解を行ない, 原料炭の種類と生成物の収率の関係 を検討している。彼らは歴青炭 (Pittsburgh 炭 Rock Springs 炭), 褐炭 (Rockdale 炭), 無煙炭 (Luzerne Count 炭), 炭質化炭 (Rock Springs 炭を $600^{\circ} \mathrm{C} に て 2$ 時間ヘリウム気流中で加熱したもの）を，モリブデンア ンモン (Mo として石炭に対し 1\%) と硫酸（石炭に対 し $0.8 \%$ ）添加して水素化分解し，石炭の炭化水素ガ スおよび液状生成物への変化率と反応時間の関係を求め た (図 3,4,5 参照)。炭化度の低い石炭程石炭の変化率 が高く, 褐炭では $97 \%$ に達しており，また液状生成物の

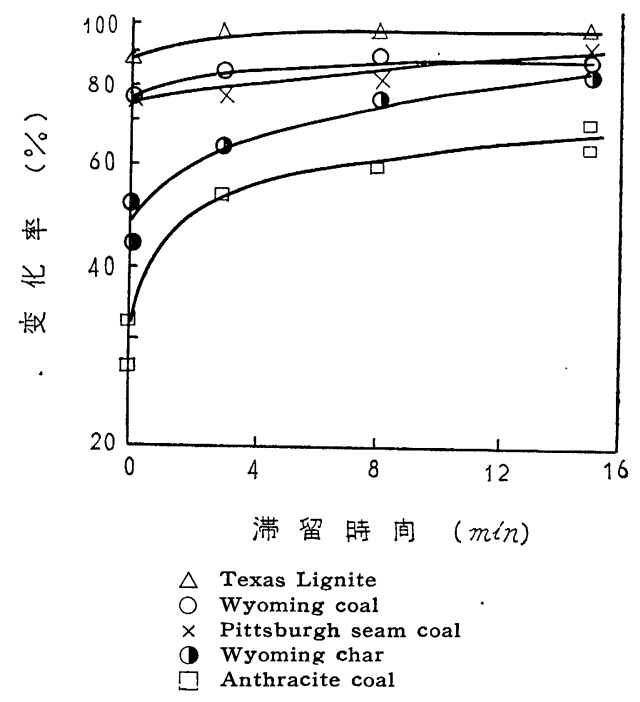

図 3

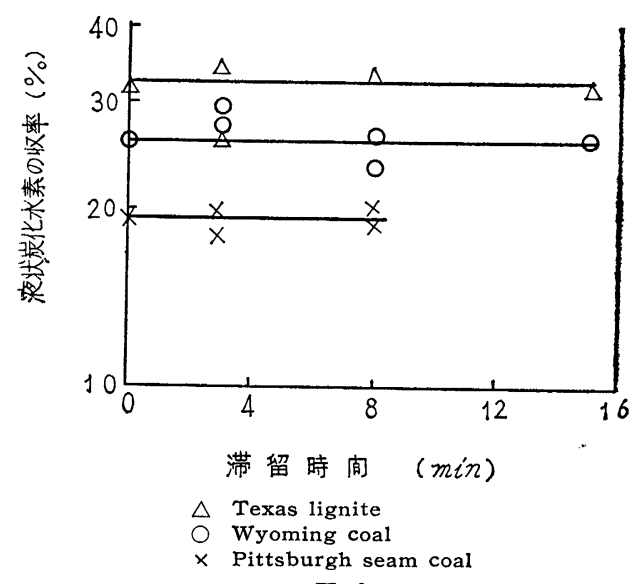

図 4

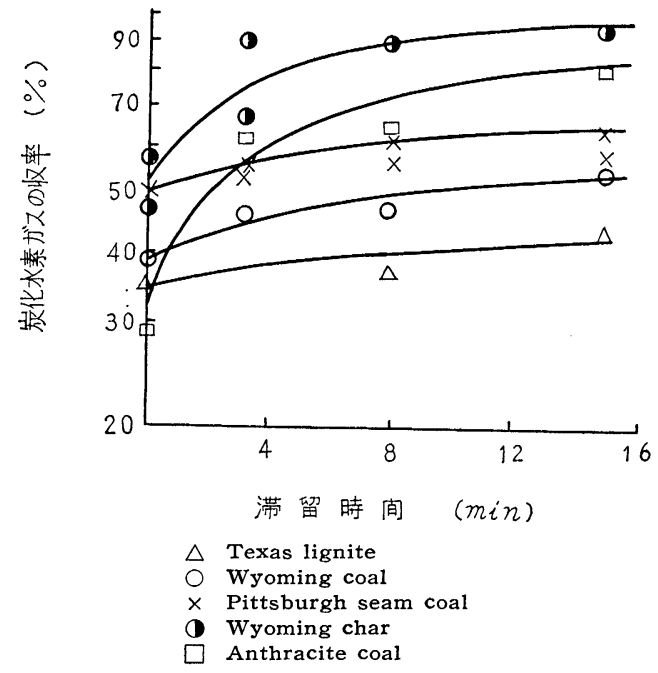

図 5

收率も低炭化度の方が高く，しかもいずれの炭種におい ても液状生成物の収率は反応時間に無関係である。液状 生成物は $400^{\circ} \mathrm{C}$ 付近から生成しはじめ, $525^{\circ} \mathrm{C}$ 前後で その生成量が急激に増加するものであるが，さらに高温 になるとクラッキングを生じ，乙たがって液状生成物の 収率は減少して来たものと考えられる。液状生成物の組 成については質量分析計などを用いて検討しているが， 炭種による本質的な相異はないもののようである。炭化 水素ガスの収率は炭化度が低下するにつれて減少し, ま た炭化水素ガス生成速度にも相異がみられる。炭化度の 影響はガス収率だけでなく，ガス組成にも影響し，炭化 度が進むとメタンの含有量が増加する傾向がある。水素 流量も生成物の収率に影響し，水素流量が増大すると液 状生成物の収率は増し, 炭化水素ガスの収率は低下寸る ようである。

さらに Hiteshue ら ${ }^{21}$ は $400 \mathrm{~atm}$ の加圧下に 450〜 $800^{\circ} \mathrm{C}$ で石炭の水素化分解を行ない, 反応過程について 検討している。触媒としてMo 無水無灰炭に対し $1 \%$ 添 加し, $450,500,800^{\circ} \mathrm{C}$ の反応温度で石炭を水素化分解し たときの結果の一部を 表 4 に示した。反応温度 $500^{\circ} \mathrm{C}$

表 4

\begin{tabular}{c|c|r|c}
\hline 反 応 & 条 件 & \multicolumn{2}{|c|}{ 生成 物 の 収率 } \\
\hline $\begin{array}{c}\text { 反応温度 } \\
\left({ }^{\circ} \mathrm{C}\right)\end{array}$ & $\begin{array}{c}\text { 滞留時間 } \\
(\mathrm{sec})\end{array}$ & $\begin{array}{c}\text { 炭化水素ガ } \\
(\%)\end{array}$ & $\begin{array}{c}\text { 液 状 物 } \\
(\%)\end{array}$ \\
\hline 450 & 40 & 1 & 2 \\
500 & 40 & 8 & 20 \\
800 & 0 & 38 & 4.5 \\
800 & 15 & 80 & 4.5 \\
\hline
\end{tabular}


$800^{\circ} \mathrm{C}$ 付近までは反応温度が上昇するにしたがって炭化 水素ガス, 液状生成物の収率はともに増加するが, 反応 温度 $800^{\circ} \mathrm{C}$ になると液状生成物の収率は $4.5 \%$ に激減 したのに対し，炭化水素ガス収率は増加してくる。これ については $400 \mathrm{~atm}$ の水素加圧下に石炭を $800^{\circ} \mathrm{C}$ の高 温に加熱すると，石炭を構成している縮合環に付いてい る側鎖などの熱分解を受け易い部分，あるいは石炭中の 挥発し易い部分が急速に分解して炭化水素ガスとなり, 石炭は炭梊化し，ついで炭質化した部分が漸次水素化分 解を受けて，石炭の大部分が炭化水素ガスとなったもの と考えられている。なお液状生成物, 炭化水素ガスの組 成を 表 5 亿示した。石炭を水素化分解して軽油, 中油

表 5

\begin{tabular}{l|c}
\hline 軽油*組成 $(\%)$ & \\
単環范香族炭化水素 & 49 \\
ナフタリン類 & 32 \\
テトラリン・メチルインダン & $($ 少量) \\
未確認物 & 18 \\
炭化水菜ガス組成 $(\%)$ & \\
メタン & 93 \\
エタンその他 & 7 \\
\hline
\end{tabular}

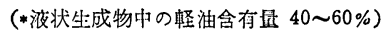

などの製造を目的とするためには，まず石炭を速かに高 分子正の液状生成物に変え，炭澌化させないことが必要 で，ついで生成した液状生成物を望む低分子化合物に変 化させることが望ましく，したがっておのおのの過 程 を選択的に促進させる触媒を見出し，これらの触媒を組 合せて目的を達成する方法が考えられる。一方, 反応温 度 $800^{\circ} \mathrm{C}$ のような高温で石炭を水素化分解して，ごく 短い反応時間で炭化水素ガスを 好収率で得た Hiteshue らの実験結果から，石炭の水素化分解により高熱量のガ スを製造する目的で微砕した石炭を水素気流に乗せて， かなり速い速度で反応管を通過させてガス化する方法も 可能であり，この反応形式を用いて石炭を水素化分解す る特許 ${ }^{22)}$ もある。このような反応形式はいろいろな問題 を含んでいるものと思われるが，粉体を取扱う技術の進 歩した今日，興味ある反応形式である。

石炭より高熱量の燃料ガスを製造する目的で石炭を水 素化分解する試みは Dent ${ }^{23)}$ らによって行なわれたが， 高熱量のガスを有利に製造することは困難であった。石 炭をメタンに変化させるには, 基本的につぎの三つの方 式が考えられる。すなわち，〔A]石炭を水と酸素で一 度ガス化して一酸化炭素にしたのち, 生成ガスを $400^{\circ} \mathrm{C}$ 附近で触媒の存在下にメタン化し，副生した炭酸ガスを
除去する方法, [B]石炭を部分水素化分解してメタン を製造し，炭質化した未反応物を水と酸素でガス化し， これより水素を回収して石炭の水素化分解に使用する方 法, および〔C]石炭を完全に水素化分解してメタンに し，その一部を水を用いて接触分解して一酸化炭素と水 素としたのち, 水素を回収して石炭の水素化分解に使用 する方法がある (図 6 参照)。Channabasappa ら ${ }^{24)}$ は
(A)

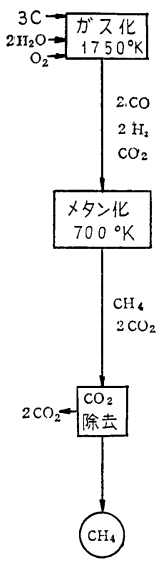

[B]

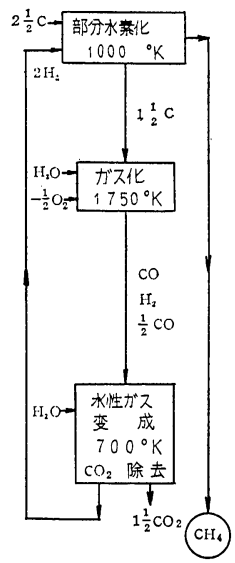

図 6
(C)

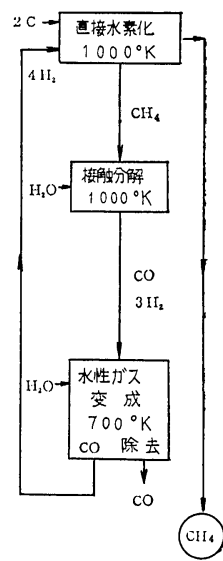

これらの三つの方式について熱収支を計算し，[B]法 の部分水素化による方式が最も有利で，ついで〔C]法 が有利であることを明らかにし，石炭の水素化分解によ るガス化を検討している。彼らは歴青炭を $100^{5} \mathrm{psig} の$ 水素初圧で水素化分解し, ガス収量と反応時間, 反応温 度の関係を検討した (図 7,8 参照)。水素初圧が增すと

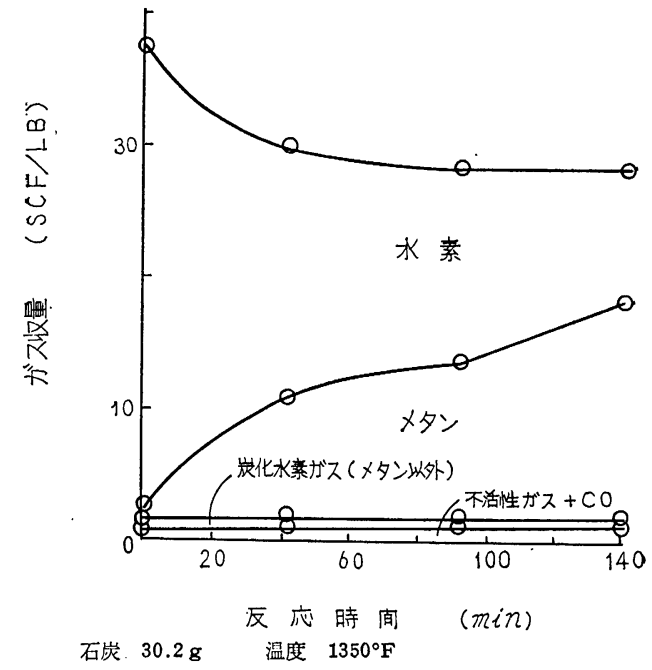

図 7 


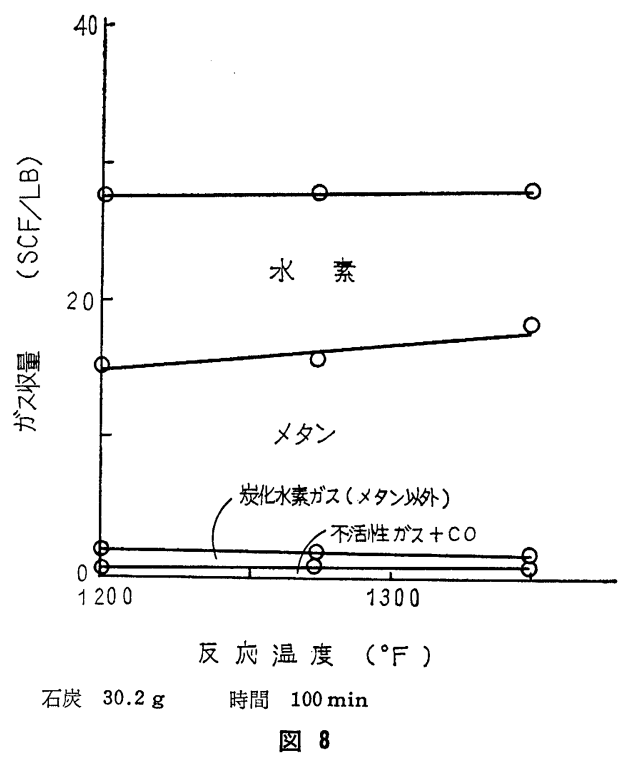

石炭の変化率は増大し, 炭化水素ガスの発生量は増す が, 生成ガス中の炭化水素含有量は小さい。モリブデン アンモン, 塩化スズなどの触媒効果は明らかでないが, 石炭を $375^{\circ} \mathrm{C}$ に $20 \mathrm{~min}$ 窒素気流中で加熱して前処理を 行うと, $730^{\circ} \mathrm{C}, 170 \mathrm{~atm}$ の条件で水素化分解してメタン の含有量 81 モル\%の生成ガスを得ている。

\section{IV. 石炭の水素化分解生成物の利用}

石炭の水素化分解によってガソリンや燃料ガスが得ら れる他に芳香族炭化水素㧍よびフェノール類も製造でき る。これらの芳香族炭化水素やフェノール類はかなり複 雑な組成の混合物であり, 目的に応じて脱アルキル化, 異性化，あるいはアルキル化などを行って有機合成原料 として利用される。

\section{1. 芳香族炭化水素のアルキル化, 脱アルキル化} ベンゼン，トルエン，キシレンなどの芳香族炭化水素は フリーデルクラフト型触媒の存在下にオンフィン, アル コール，八ロゲン化アルキルなどと反応してアルキル化 される。工業的には，たとえばベンゼンはエチレン，プ ロピレンなどでアルキル化されてェチルベンゼン，イソ プロピルベンゼンが製造され，スチレンやフェノールの 製造原料となっている。最近においてもベンゼンのプロ ピレンによるアルキル化が硫酸 ${ }^{25}$ やフッ化ホウ素触媒 ${ }^{26)}$

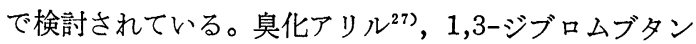
${ }^{28)}$, エチレンの水和反応にて副生する長鎖オレフイン ${ }^{29)}$ などによるベンゼンのアルキル化も検討されている。ト ルエンのプロレンによるアルキル化についても塩化アル
ミニウム ${ }^{30)}$, シリカ・アルミナナ11などの触媒を用いて検討 され,その他 $\mathrm{C}_{8 \sim 12}$ のオレフィンによるアルキル ${ }^{32,33}$ 化も みられている。シリカ・アルミナ触媒でトルエンを共存さ せて $n$-ペンタンを熱分解させるキシレンの合成 ${ }^{34)}$, ポリ スチレンスルホン酸触媒でオレフィンによるベンゼン， トルエンのアルキル化 ${ }^{35}$ なども行なわれている。その他， キシレンの 1,1-ジメチル-1-クロルプロパンによるアル キル化 ${ }^{36)}$ ，メジチレンのフランによるアルキル化 ${ }^{37)}$, ナ フタリンのプロピレンによるアルキル化な ${ }^{38)}$ ども研究さ れている。これらのイオン反応に対して高温高圧ではラ ジカル機構が提案 ${ }^{39}$ されているが, たとえば $400 \sim 500^{\circ} \mathrm{C}$ 300 400 atm の条件でのアルキルベンゼンとオレフィ ンのラジカル的なアルキル化反応も検討されている ${ }^{40)} 。$

アルキルベンゼンを脱アルキル化して需要の多い芳香 族炭化水素を製造することもアルキルベンゼンの利用に 関して重要な手段であり，最近においてもニッケル・ケ イソウ土触媒 $320 \sim 360^{\circ} \mathrm{C}$ で水蒸気を共存させておこな らトルエンの脱メチル化 ${ }^{41)}$, 水素添加分解によるトルエ ンの脱メチル化 ${ }^{42,43)}, \mathrm{C}_{7 \sim 10}$ の芳香族炭化水素をクロム. リン酸触媒で脱メチル化してベンゼン，トルエンを製造 する方法 ${ }^{44)}$ など，また，1,2,4-トリメチルベンゼンを $\mathrm{MoO}_{3} \cdot \mathrm{CoO} \cdot \mathrm{NaOH}-\mathrm{Al}_{2} \mathrm{O}_{3} \cdot \mathrm{SiO}_{2}$ 触媒で水素添加分解し てキシレンを製造する方法 ${ }^{45}$, 高沸点芳香族炭化水素を 水素添加分解してキシレン製造する方法 ${ }^{46)}$, ヘキサメチ ルベンゼンの $\mathrm{NiS}-\mathrm{Al}_{2} \mathrm{O}_{3}$ 触媒での水素添加分解などの 研究 ${ }^{47)}$ ，などがみられる。

2. 芳香族炭化水素の異性化, 不均化 アルキルベ ンゼンの異性化はフリーデルクラフト型触媒, シリカ・ アルミナ触媒，金属・酸性担体型触媒などによって促進 される。アルキルベンゼンのらちとくにキシレンの異性 化は工業的に重要で,多くの研究, 特許がみられる。キシ レンの異性化をフリーデルクラフト型触媒を用いて行な うときは液相で比較的低温で異性化し, 触媒量が増すに つれて熱力学的平衡組成からずれて $m$-キシレン量が増 加してくる ${ }^{48}$ 。シリカ・アルミナ触媒を用いてキシレン を異性化するには $500^{\circ} \mathrm{C}$ 前後の反応温度で行なわれる が, 不均化, 脱アルキル化反応も一部おこる。異性化を 促進し, 副反応を抑制するために水素あるいは水蒸気を 共存させで ${ }^{49)}$, あるいはまた減圧下で反応させる場合も ある ${ }^{50)}$ 。最近においてもシリカ・アルミナ触媒の構造と 異性化能に関する報告 ${ }^{51)}$ や応速度論的研究, 触媒の酸 性度や表面積などと異性化能に関する研究52) みられ る。金属・酸性担体型触媒を用いる場合は白金シリカ・ アルミナ触媒などが用いられ，水素加圧下に反応を行な うものであるが，この場合はモノアルキルベンゼンから 
ポリアルキルベンゼンに異性化する反応もおこる る の反応はベンゼン環の水素添加, シクロヘキサンからシ クロペンタンヘの異性化, シクロペンタンの脱水素によ るアルキルベンゼンの生成の三段階を経て進行すると考 えられており，したがって最初に $\mathrm{Ni}, \mathrm{Co}, \mathrm{Pt}, \mathrm{Pd}$ などを 含んだシリカ・アルミナ触媒で, ついでクラッキング能 の強い触媒を用いて二段に異性化する方法 ${ }^{54)}$ ある。そ の他 $(\mathrm{EtO})_{3} \mathrm{PO}$ 触媒で混合キシレンよりp-キシレン含 有量の多いキシレンに異性化する特許 $\left.{ }^{55}\right)$ もる。

アルキルベンゼンはフリーデルクラフト型触媒で異性 化と同時に分子間でアルキル基の移動がおこり, 不均化 をおこす。最近, Schriesheim ${ }^{56)}$ は $\mathrm{AlBr}_{3} \cdot \mathrm{HBr}$ 触媒で トルエンの不均化を検討し, 反応温度 $80.6^{\circ} \mathrm{C}$ ではベン ゼンとキシレン（主として $m$-キシレン）が生成するが 変化率を高めると小量ながら $\mathrm{C}_{9}$ (主としてメシチレン) $\mathrm{C}_{10}$ 芳香族炭化水素も生成することを確認している。反忘 温度が $110^{\circ} \mathrm{C}$ となると $\mathrm{C}_{9}, \mathrm{C}_{10}$ 留分が増加し, キシレンの 異性化がおこる。その他, $\mathrm{HF} \cdot \mathrm{BF}_{3}$ 触媒でトルエンを不 均化する特許 ${ }^{57)}$ やルエンとポリメチルベンゼンを $\mathrm{HF}$ 触媒 ${ }^{58}$ ) シリカ・アルミナ触媒 ${ }^{59}$ )

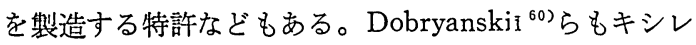
ン, エチルトルエン, ブチルトルエン, シクロヘキシル トルエンの不均化を研究しており, Mamedaliev ら ${ }^{61)}$ も シリカ・アルミナ触媒, $480^{\circ} \mathrm{C}$ の条件でキシレン, 1,2 ,

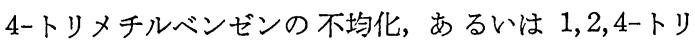
メチルベンゼンとベンゼンまたはトルエンの混合物, メ シチレンとベンゼンの混合物などの不均化について研究 している・

3. 芳香族炭化水素のクロルメチル化 ベンゼンあ るいアルキルベンゼンをホルマリンと塩酸でクロルメチ ル化し, 加水分解, 酸化, 㯰換反応などを行なって有機 合成原料とすることができる。

i. ベンゼンのクロルメチル化 ベンゼンを ホルマリ ンと塩酸で塩化垔鉛の存在下にクロルメチル化すると好 収率で塩化ベンジルを生成する。さらに塩化ベンジルを クロルメチル化すると $p$-および $o$-ジクロルメチル化物 となる ${ }^{62)}$ 。

ii. トルエンのクロルメチル化 トルエンをクロル メチル化し，ついで酸化してテレフタル酸を製造する方 法は Grosskinsky 法として知られているが，この方法 の改良法が $\mathrm{Glas}^{63)}$ により示めされた。この改良法は塩 化亚鉛などを使用せず，反応中は常に塩酸の濃度を商く 保ってクロルメチル化を行なうもので，2 3 hr で反応 率 $98 \%$ に達し，ビスクロルメチル化物などの副生物が 小なく，p-および oークロルメチル化物の組成はそれぞ
れ 57\%，43\% である。生成したクロネメチルトルエン の硝酸酸化については Benning ${ }^{64)}$ の報告があり，クロ ルメチル基を加水分解したのち酸化する方法むある ${ }^{65)}$ 。 また $p$-および oークロルメチル化物の混合物を光照射下 に塩素化し, ついで加水分解してテレフタル酸とフタ ル酸アルデヒドにしたのちテレフタル酸を容易に分離製 造㬏すこともできる。

iii. キシレンのクロルメチル化 キシレンもベンゼ ン, トルエンと同様にクロルメチル化される。筆者 ${ }^{67) ら ~}$ も $m$-キシレンをクロルメチル化し, 検討している。

iv. トリメチルベンゼンのクロルメチル化 Lake と Corson $^{68)}$ は 1,2,4-トリメチルベンゼンをクロルメチル 化し 1,2,4-トリメチルベンゼンの $78 \%$ をクロルメチル 化したが，クロルメチル化生成物はつぎのような混合物 である。

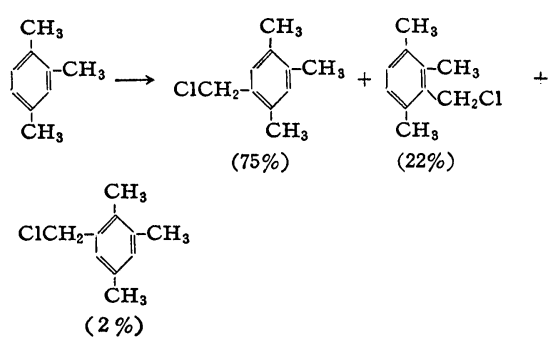

彼らは主生成物である 1,2,4-トリメチル-5-クロルメ チルベンゼンの加水分解や過マンガン酸カリ酸化による 1,2,4,5-ベンゼンテトラカルボン酸の合成なども行なっ ている。その他 1,2,4-トリメチルベンゼンのクロルメ チル化物を水素化して 1,2,4,5-テトラメチルベンゼン を製造 ${ }^{69)}$ することもできる。

1,3,5-トリメチルベンゼンをホルマリンと塩酸で, 塩 化亜鉛と塩化ナトルウムを添加して $15 \mathrm{hr}$ 還流下に加熱 してモノクロルメチル化物 $(6 \%)$, ジクロルメチル化物 $(41 \%)$ ，トリメチル化物 $(51 \%)$ を得る特許 $\left.{ }^{70}\right)$ もるが， 一方簐者 ${ }^{71}$ らも研究をつつけている。

v. テトラメチルベンゼンのクロルメチル化 $1,2,4$, 5-テトラメチルベンゼンをクロルメチル化すればモノ， およびジクロルメチル化物を得る ${ }^{72)}$ 。これをジオキサン 中で塩化鉄あるいは金属ナトリウムで重合させたり，加 水分解ののちポリエーテルにすることもできる ${ }^{72)}$ 。また ナトリウムマロン酸エステルと反応させ, 加水分解, 脱 炭酸を行って二塩基酸としたのち，グリコールなどと区 応させてポリエステルにすることもできる ${ }^{73)} 。$

4. アルキルベンゼン, ナフタリン類の酸化 ベン ゼンカルボン酸類はアルキルベンゼンの硝酸酸化, 空気 酸化，あるいはイオウによる酸化などで製造され得る。 
とくに p-キシレンの酸化によるテレフタル酸の製造は 重要である。

i. 硝酸酸化 アルキルベンゼン，たとえば $p$-キシ レンを硝酸酸化すると, 反応温度 $130^{\circ} \mathrm{C}$ 以下では主とし て $p$-トリル酸が生成し, 反応温度 $150^{\circ} \mathrm{C}$ 以上, とくに $200^{\circ} \mathrm{C}$ 前後ではテレフタル酸が主生成物となる。したが って p-キシレンを $p$-トリル酸まで酸化し， $p$-トリル 酸をエステル化したのち酸化してテレフタル酸を製造す る三段酸化法や一段酸化の办法がとられている。硝酸濃 度は $25 \sim 40 \%$ 程度のものが用いられ，p-キシレンに対 する硝酸量も問題になる。また酸素を共存させて硝酸酸 化することも考えられていかる(74)。クロルメチルトルエン やジイソプロピルベンゼン ${ }^{75)}$ な゙も硝酸酸化されてベン ゼンジカルボン酸となる。

ii. 液相空気酸化 トルエンやキシレンをCo 塩触媒 などの存在下に液相空気酸化して高収率でベンゼンカル ボン酸を製造することができる。Brill ${ }^{76)}$ は氷酢酸に溶 解させた $p$-キシレンを Co-酢酸塩触媒で, メチルエチ ルケトンを添加して $90^{\circ} \mathrm{C}$ にて酸素を導入しながら $24 \mathrm{hr}$ 反応させて，テレフタル酸を $93 \%$ の収率で得ている。 この場合 $\mathrm{NH}_{4} \mathrm{Br}$ を触媒として添加する方法 ${ }^{77)}$ むる。 Coーオレイン酸塩触媒でキシレンを二段に空気酸化する 方法も Khchanyan ${ }^{78)}$ らによって検討されている。そ の他, キシレンを Coーステアリン酸塩触媒で 70 atm の 加圧下に $180^{\circ} \mathrm{C}$ で酸化する方法 ${ }^{79}$, ジェチルベンゼン をCo-ステアリン酸塩触媒で空気酸化してベンゼンジカ ルボン酸を製造する方法 ${ }^{80)}$ ，あるいは (Co-ナフテン酸塩触媒で キシレン ${ }^{81)}$, ジイソプロピルベンゼン年), メチルナ ${ }_{\mathrm{Cl}} \mathrm{CCl}_{3}$ フタリン ${ }^{83)}$ などを空気酸化することも できる。また酢酸マンガン触媒でトリ

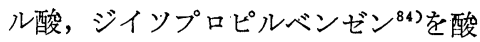
化することもでき，系化マンガンと臭 化コバルトを触媒としてベンゾニトリ ル ${ }^{85)}$ や安息香酸中 ${ }^{86)}$-゙゙キシレンを空気 酸化する例もみられる。

iii. 気相空気酸化 アルキルベン ゼンを気相空気酸化するには五酸化バ ナジウム系の触媒が用いられる。ナフ タリンを五酸化バナジウム触媒で気相 空気酸化して無水フタル酸を製造する ことはよく知られている。森田 ${ }^{87)}$ は $\mathrm{V}_{2} \mathrm{O}_{5}-\mathrm{MoO}_{3}$ 触媒を用いてトルエン, トリメチルベンゼン, メチルナフタリ 類，およびアセナフテンの気相酸花
を検討しており， $\mathrm{SiO}_{2} \cdot \mathrm{K}_{2} \mathrm{O} \cdot \mathrm{V}_{2} \mathrm{O}_{5}$ 触媒でナフタリンを 酸化している例も ${ }^{88)}$ ある。その他 $\mathrm{MoO}_{3}, \mathrm{TiO}_{2}, \mathrm{Cr}_{2} \mathrm{O}_{3}$ な どを含んだ $\mathrm{V}_{2} \mathrm{O}_{5}$ 触媒でベンゼン, トルエン, キシレン の酸化が検討され ${ }^{89)}, \mathrm{Tl}, \mathrm{Ag}, \mathrm{K}, \mathrm{Na}, \mathrm{Li}, \mathrm{Rb}$ などのバナ ジン酸塩触媒 ${ }^{90)}, \mathrm{V}_{2} \mathrm{O}_{5} \cdot \mathrm{MoO}_{3} \cdot \mathrm{P}_{2} \mathrm{O}_{5}$ 触媒 ${ }^{91)}$ も研究され ている。フェナントレン ${ }^{92)}$ やジメチルナフタリン ${ }^{93)}$ \& $\mathrm{V}_{2} \mathrm{O}_{5}$ 触媒で気相空気酸化して無水フタル酸にすること ができる。

iv. イオウまたは硫化物による酸化この方法はア ンモニアと水の存在下にイオウでアルキルベンゼンを酸 化する方法と硫酸アンモニウム水溶液中で硫化物で酸化 する方法がある。いずれも加圧下に反応温度 $300 \sim 350^{\circ} \mathrm{C}$ の条件で酸化するもので，p-キシレンからぼ約 95\%の 収率でテレフタル酸を得る。Toland ${ }^{94)}$ はイオウと水に よるアルキルベンゼンの酸化について詳細に検討し，そ の反応機構について考察している。

アルキルベンゼンを $\mathrm{SO}_{2}$ と共に $\mathrm{V}_{2} \mathrm{O}_{5}$ 触媒に 350 $400^{\circ} \mathrm{C}$ で接触させて酸化する方法もあり ${ }^{95)}$ ，トルエン, キシレン,イソプロピルベンゼンなどについて試みられ ている。

v. その他 アルキルベンゼンを重クロム酸ナトリウ $ム^{96)}$ ，または過マンガン酸カリで酸化した研究 ${ }^{973}$ や臭 化水素水溶液中で酸素または過酸化水素による酸化 ${ }^{98}$ な どの研究もみられる。

5. ベンゼン, トルエン, キシレン, ナフタリンの利 用 ベンゼン，トルエンの用途を図9.10にまとめた。<smiles>Clc1ccc(C(c2ccc(Cl)cc2)C(Cl)(Cl)Cl)cc1</smiles>
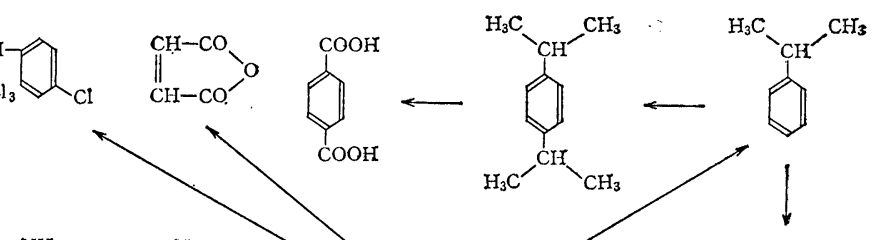
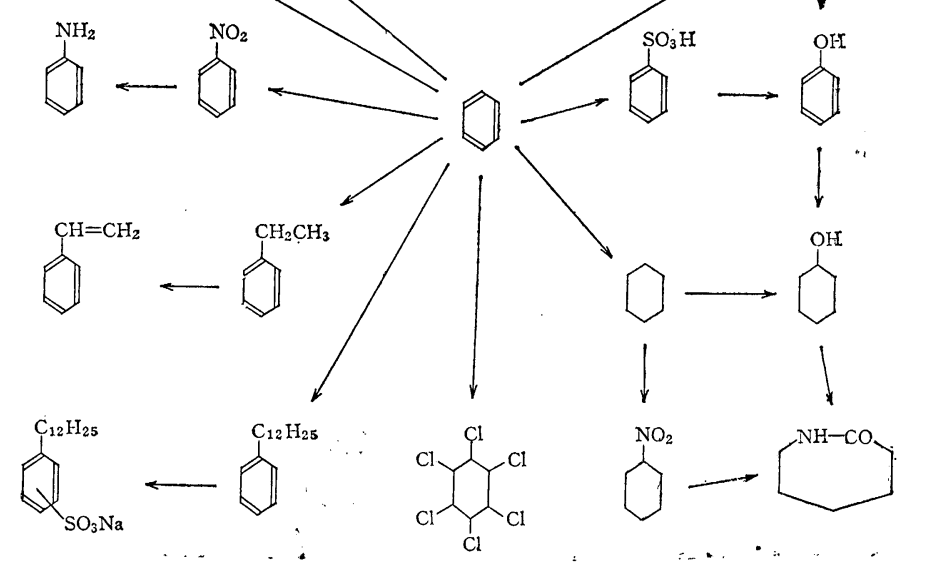

図 9 


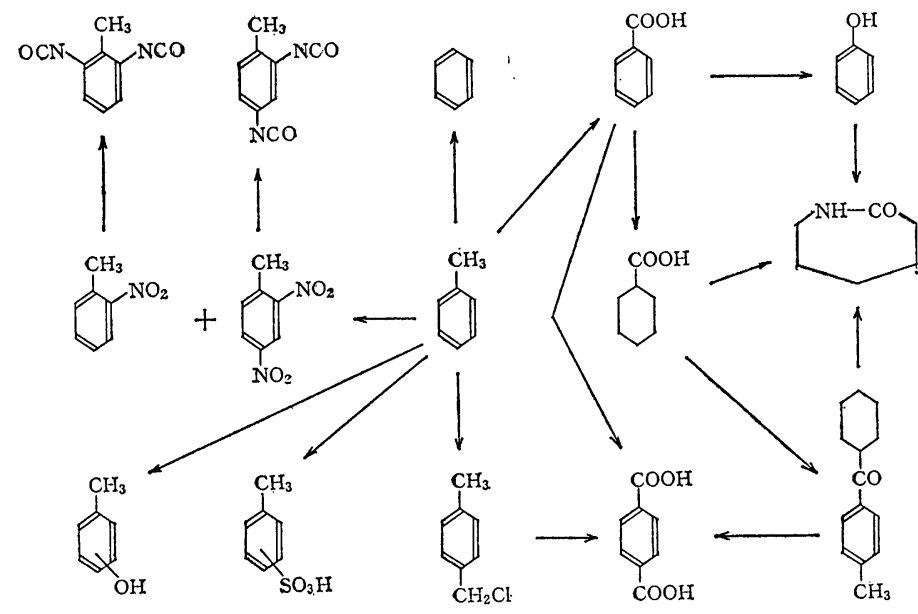

図 10

これらについては筆者がタール製品と有機合成 ${ }^{99)}$ と題し てコールタール誌に発表しているので省略するが，これ らの芳香族炭化水素の用途開発研究もさかんにおこなわ れてきた。たとえばシクロへキサン酸化法, ニトロシク ロヘキサン法, 塩化ニトロシル法などによるシクロヘキ サノンオキシム製造法が発見されたためベンゼンからカ プロラクタム製造への道がひらけた。またスニア法によ るカプロラクタムの製造, ヘンケル法によるテレフタル 酸の製造, ダウ法によるフェノールの製造などにより安 息香酸を径るトルエンの用途も大いに開発されている。 野ロ ${ }^{100)} ら$ むぎの径路でトルエンから芳香族カルボン 酸とフェノールの同時合成法を研究している。
ールおよび高沸点のフェノール類よりなる が，このうち最も需要の多いのはフエノー ルであり，したがってアルキルフエノール より脱アルキル化してフエノールを製造す る研究がひろく行なわれている。クレン゙ー ルやキシレンノールから脱メチル化してフ エノールを合成するには熱分解 ${ }^{102)}$ ，接触 分解 ${ }^{103)}$, 水素添加分解 ${ }^{104)}$ などの方法があ る。水素添加分解においてはつぎの反応が. 同時におこり，反応は複雑である。

最近においても $\mathrm{Ni}-\mathrm{Al}_{2} \mathrm{O}_{3}$ 触媒で $350^{\circ} \mathrm{C}$ 常圧の条件でクレゾールの脱メチル化が. ${ }^{105,106)}$ 検討され，クレゾールの反応性は $O^{-}$

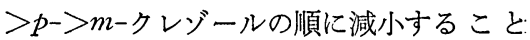
が認められており，また $\mathrm{Ni}-\mathrm{Al}_{2} \mathrm{O}_{3}$ 触媒上 に $410 \sim 470^{\circ} \mathrm{C}$ でクレゾールを水蒸気と共に送って $m$ -

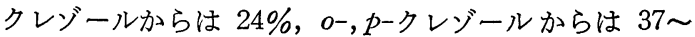
40\%の収率でフェノールが生成することが見出されてい る $^{107)}$ 。Ronald Long ${ }^{108)}$ らも $600 \sim 700^{\circ} \mathrm{C}, 30 \mathrm{~atm}$ の加? 圧下にクレン゙ール，キシレノールなどをコークスに接触 させながら水素添加分解を行なって脱メチル化し，クレ ゾールからはフェノールとトルエンが，キシレノールか らは主としてクレン゙ールが生成し，クレゾールの反応性

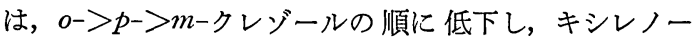
ルの反応性は $2,3->2,4->2,6-, 3,4->2,5->3,5$-キシ レノールの順に減小することを認めている。その他, $\mathrm{Cr}_{2}$ $\mathrm{O}_{3}-\mathrm{Al}_{2} \mathrm{O}_{3}$ 触媒で水素添加分解する特許 ${ }^{109)}$ もる。

フエノールはほとんどが ナイロンの製造原料として 使用されるが，フエノール 樹脂やビスフエノール-A， アルキルフェノールなどの 製造にも用いられている。

一方フェノールと炭酸ガスとの Kolbe-Schmidt 反応 によってサリチル酸，パラオキシ安息香酸が生成するが これらはすでに医薬品として，あるいは食品防徽剤とし て広く使用されている。特にパラオキシ安息香酸は最近 ポリエステルエーテル系合成繊維の登場ならびにポリエ チレンテレフタレート繊維の改質のための原料として注 目をあびている。

筆者らもこの Kolbe-Schmidt 反応によるパラオキシ 安息香酸の生成機構について研究 ${ }^{110)}$ をすすめいるが さきに次の如き反応機構 ${ }^{111}$ を提案した。すなわち 石炭 酸カリウム塩に炭酸ガスを 反応させて Kolbe-Schmidt 反応を行なう場合，この石炭酸カリウム塩と炭酸ガスと 
の複合物よりまず低温でサリチル酸モノカリウム塩とパ ラオキシ安息香酸モノカリウム塩が生成する。このサリ チル酸モノカリウム塩はその 2 分子より 1 分子のサリチ ル酸ジカリウム塩と石炭酸になり, 得られたサリチル酸 ジカリウム塩が転位してパラオキシ安息香酸ジカリウム 塩になる。すなわち生成したパラオキシ安息香酸カリウ ム塩にはモノカリウム塩とジカリウム塩の二つが存在す ることを明らかにした。

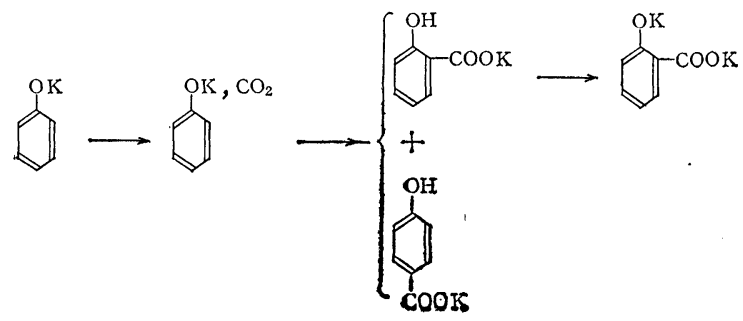

\section{V. 結語}

前回の石炭の酸化仁ひきつづいて石炭の水素化分解の 動向とその生成物の利用について概観した。これらは石 炭化学のうちもっとも積極的に石炭の特質を有効に利用 しょうとする分野であり，しかも有機合成化学原料を供 給しょうとするもので, 現在の有機化学工業に密接に結 びついており, その発展は注目され, 期待されるもので 弯る。

(昭和 38 年 9 月 16 日受理)

\section{文献}

1) F.I.A.T. Final Report No. 952

2) L. C. Skinner, et al, Ind. Eng. Chem. 4187 (1949) J.A. Markovits, et al., Trans. Am. Soc. Mech. Engrs. 72349 (1950) E.A. CIarke, et al., Bur. Mines. Rept. Invest. No. 4944 (1953) C. C. Chaffee, L. L. Hisst, Ind. Eng. Chem, 45822 (1963)

3) Chem. Eng. News. 301739 (1952)

4) E.E. Donath, Mining Eng. 4381 (1952)

5) H.H. Stoeh, et al. J. Soc. Chem. Ind. (London) 69121 (1950)

6) E.E. Donath, Ind. Eng. Chem. 462032 (1954)

7) J.R. Collaham, Chem Eng. 59152 (1952); S.D. Kirkpatrick, Chem. Eng. 60180 (1953)

8) R.W. Hiteshue, et al., U.S. Bur. Mines. Rept. Invest. No. 5674,57 p.p, (1960)

9) USP 2, 860, 101 (1958)

10) G.P (East) 12, 808 (1957)

11) USP 3, 018; 241, (1962); USP 3,018, 242 (1962)

12) 坂部 5 , 工化 63545 (1960) ibid.65 297 (1962) ibid 66735 (1963)

13) J.H. Howell. et al., USP 2,913,388 (1959)

14) J.V. Munay, Jr., et al., USP 2,913,397 (1959)

15) R.W. Hiteshue, et al., U.S. Bur. Mines. Rept. Invest. No. 5673, 35 pp. (1960)
16) R.W. Hiteshue, et al., U.S. Bur. Mines. Rept. Invest. No. 6021, 12 pp. (1962)

17) S.K. Bose, et al.,J. Sci. Ind. Research. (India) 18-B 255 (1959)

18) R.W. Hiteshue, et al., U.S. Bur. Mines. Rept. Invest. No $590814 \mathrm{pp}$ (1961)

19) R.W. Hiteshueetal., Ind. Eng. Chem. 492008 (1957)

20) R.W. Hiteshue, et al., Ind. Eng. Chem. 52577 (1960)<smiles>CC(=O)OC(C)=O</smiles>

21) R. W. Hiteshue, et al., U.S. Bur. Mines. Rep. Invest. No. 6027, 25 pp. (1962)

22) USP 3,030,297 (1962)

23) F.J. Dent, Gas J. 224502 (1944)

24) K.C. Channabasappa, H.R. Linden, Ind. Eng. Chem. 48900 (1956)

25) Kh. R. Ruotamov, T.P. Porshakova Doldaay. Akad. Nauk Uzbek. S.S.R. 1960 No 432, CA 567182 (1962)

26) A.V. Topchiev, et al., CA 5613156 (1962)

27) Yu. G. Mamedaliev, et al.,Azerbaidzhan. Khim. Zhur. 1961 No. 2, 3;CA 562356 (1962)

28) I.P. Tsukervanik, et al., Zhur. Obshchei. Khim. 312143 (1961);CA 56362 (1962)

29) M.M. Movsumzade, R.A. Shikhalieve, Azerb. Khim. Zh 1961 No. 3, 61 CA 5613036 (1962)

30) B.L. Kozik, et al., Khim. i Tekhnol. Topliv. i Masel. 6 No. 10,9 (1961); CA 566241 (1962)

31) Yu, G. Mamedalev, et al., Azerbaidzhan. Khim. 1961 No 1, 39;CA 5610001 (1962)

32) E.B. Sokolova, et al., CA 567181 (1962)

33) Yu. I. Kozov, et al., CA 5610452 (1962)

34) A.A. Buniyat-zade, et al., CA 56360 (1962)

35) USP 3,017,441 (1957)

36) USP 3,000,985 (1958)

37) Ch. Sh. Kadyrov, et al., CA 565855 (1962)

38) A.V. Topchiev, et al., CA 562391 (1962)

39) Pines, Arrigo, J. Am. Chem Soc. 7.9958 (1957)

40) H. Pines, Chem. Ind. 12954 (1961)

41) T.A. Slovokhotova, et al., CA 5614977 (1962)

42) D.H. Stormont, Oil. Gas J. 59 No. 46. 160 (1961)

43) A.H. Weiss, et al., Oil. Gas J. 60 No. 4, 64, 69 (1962)

44) A.D. Sulimov, et al., CA 56408 (1962)

45) USP 2,960,545 (1960)

46) USP 2,983,670 (1961)

47) R.F. Sullivan, et al., J. Am. Chem. Soc. 83 1156 (1961)

48) D.A. McCaulay., J. Am. Chem. Soc. 746246 (1952)

49) USP 2,564,388 (1951)

50) E. Boedecker, W. Erner, J. Am. Chem. Soc. 
763591 (1954)

51) 岩崎ら, 工化 63 1957, 1980 (1960)

52) T.Amamiya, et al., Bull. Japan Petrol. Inst. 3 14 (1961)

53) P.M. Pitts, gr., et al., Ind. Eng. Chem. 47770 (1955)

54) $G P 1,059,421(1954)$

55）日特部，昭 35-18361

56) A. Schrieshein, J. Org. Chem. 263530 (1961)

57) USP 3,006,977 (1960)

58) USP 2,954,414 (1960)

59) $G P 974,703$ (1953)

60) A.F. Dobryanskiı, et al., CA 5527152 (1961)

61) G.M. Mamedaliev, et al., CA 556412 (1961); ibid.55 22189 (1961)

62）安䅡，林，工化 55476 (1952)

63) W.Glas, Angew. Chem. 72573 (1960)

64) A. Benning, Amgew.Chem. 72573 (1960)

65) GP 1,102,128 (1958)

66) $F P 798,727$

67）平尾ら，タール工羓研究会発表 (1962)

68) R.D. Lake, B.B. Corson, J. Org. Chem. 241823 (1959)

69) USP 2,977,395 (1961)

70) USP 2,973,391 (1961)

71）平尾ら，タール工業年会にて発表（昭和 37 年 10 月)

72) M.J. Rhoad, P.J. Rhoad, J. Am. Chem. Soc. 722216 (1950)

73) USP $2,939,863$

74) USP 3,017,433 (1954)

75) I. V. Butina, et al., CA 567201 (1962)

76) W.F. Brill., Ind. Eng. Chem. 52835 (1960)

77) T. Slosar, et al., $C A 568644$ (1962)

78) Kh. E. Khchanyan, et al., CA 561389 (1962)

79) $G P$ (East), 19252 (1960)

80) USP 3,014,961 (1959)

81) USP $3,004,066$ (1958)

82) $G P 1,106,751$ (1959)

83) $B P 877,002$ (1958)
84) $G P 1,112,972$ (1955)

85) GP 1,117,099 (1960)

86) $B P 877,677$ (1959)

87）森田，日化 80509 (1959)

88) USP 3,000,908 (1959)

89) I.I Ioffe, et al., CA 565437 (1962)

90) USP 3,012,043 (1958)

91) $G P$ 1,115,241 (1959)

92) C.S.B. Nair, et al., J. Sci. Ind. Research (India) 19-A 445 (1960)

93) C.J. Norton, Bull. Chem. Soc. Japan. 341545 (1961)

94) Wm, G. Toland, Jr., J. Org. Chem. 262929 (1961)

95) T.H. Strickland, Ind. Eng. Chem. 537 (1961)

96) R.H. Reitsema, et al., J.Org. Chem. 27 27(1962)

97) 平尾ら, 日化 15 年会にて発衣

98) J.E. Mc Intyre, et al., J. Chem. Soc. 19614082

99) 平尾, コールタール 14605 (1962)

100）野口ら, 有合化 $21377,385,391,466,520$ (1963)

101) L.A.' Errede, J. Am. Chem. Soc. 79 4952, 6507 (1957); 82 436, 3653, 5218, 5224, (1960)

102) M.B. Neuworth, et al., Ind. Eng. Chem. 442872 (1952); 452704 (1952)

103) M.B. Neuworth, et al., J. Am. Chem. Soc. 76 6169 (1954); P.H. Given, J. Appl. Chem. 7172 182 (1957)

104) M.B. Neuworth, BP 743,707 (1956)

105）平尾ら，昭和 34 年 11 月，日化九州支部常会にて 発表

106) F. Jost, V. Barant, CA 5610003 (1962)

107) A.A. Balandin, CA 5614138 (1962)

108) Ronald Long et al., Ind. Eng. Chem. 5310 (1961); Ind. Eng. Chem. Process. Design. Develop. 1 No 173 (1962)

109) USP 2,998,457 (1958)

110）平尾ら，昭和 38 年 11 月有機合成綜合研究発表会 にて発表

111) 平尾ら, 工化 641213 (1961) 